\title{
Premarital Sickle Cell Genetic Screening Knowledge, Attitude and Practice Compared Among Married and Unmarried Youths in Nigeria
}

\author{
Tajudeen Olusegun Rasheed ${ }^{1, \text { * }}$, Wasiu Adebowale Afolabi ${ }^{2}$, Rukayat Ololade Abdul Rasheed ${ }^{3}$, \\ Rasheedat Adenike Ajala ${ }^{4}$ \\ ${ }^{1}$ Medical Department, Economic and Financial Crimes Commission, Ikoyi, Nigeria \\ ${ }^{2}$ School of Post Basic Psychiatric/Mental Health Nursing, Federal Neuropsychiatric Hospital, Yaba, Nigeria \\ ${ }^{3}$ Tarukah Resources Consult, Agege, Nigeria \\ ${ }^{4}$ Department of Nursing, National Open University, Victoria Island, Nigeria
}

Email address:

rashtaj2005@yahoo.com (T. O. Rasheed)

${ }^{*}$ Corresponding author

\section{To cite this article:}

Tajudeen Olusegun Rasheed, Wasiu Adebowale Afolabi, Rukayat Ololade Abdul Rasheed, Rasheedat Adenike Ajala. Premarital Sickle Cell Genetic Screening Knowledge, Attitude and Practice Compared Among Married and Unmarried Youths in Nigeria. World Journal of Public Health. Vol. 3, No. 3, 2018, pp. 76-82. doi: 10.11648/j.wjph.20180303.12

Received: June 17, 2018; Accepted: July 9, 2018; Published: August 9, 2018

\begin{abstract}
Premarital sickle cell genetic screening is a test that determines the genotype of the intending couple before marriage. As a result, counseling is given before and after the test. This study assessed and compared the level of knowledge, attitude and practices of premarital sickle cell screening among married and unmarried youths in Epe, Nigeria. A crosssectional descriptive research design was used to examine 370 participants, using stratified sampling technique. Data were collected with an instrument and analyzed, stating the mean, frequency and standard deviation. Scores were built for knowledge, attitude and practice. Chi-square test with $p<0.05$ was used to test the hypotheses. The study revealed that an association exists between knowledge and practice of premarital sickle cell genetic screening among unmarried $\left(X^{2}=6.359\right.$, Cramer's v $=0.09, p=0.0116, d f=1)$ and married $\left(X^{2}=12.9325\right.$, Cramer's v $\left.=0.10, p=0.0003, d f=1\right)$ youths. Similarly, an association exists between attitude and practices of premarital sickle cell genetic screening for unmarried youth $\left(X^{2}=20.3077\right.$, $p=0.0007$, Cramer's v $=0.17, d f=1)$ but for married youths there was no association $\left(X^{2}=0.0168, p=0.8969\right.$, Cramer's $\mathrm{v}=0.08, d f=1$ ). Furthermore, finding revealed that $77 \%$ of the married participants did not have sickle cell genetic screening test before marriage, while $67 \%$ of the unmarried participants were not willing to carry out the test, due to fear of the unknown and stigma. Conclusively, the level of knowledge of the participants' was good (70.06\%), attitude was negative towards practices of premarital sickle cell genetic screening. Therefore, continuous health education that focuses on sickle cell genetic screening test could improve the practices among the youth to avert the associated morbidity and mortality.
\end{abstract}

Keywords: Premarital, Genetic Screening, Sickle Cell Disease, Youth, Nigeria

\section{Introduction}

Sickle cell disorder is one of the genetic diseases affecting Nigerians and its effective eradication and management constitute a challenge to both parents and health professionals due to the transmission of the genetic trait from parents to offspring, frequent hospitalization of the affected persons and associated mortality [1]. Despite major advances in molecular pathology that determines the causes of genetic disorders, infants and children are still dying of sickle cell disorder in Nigeria due to lack of appropriate screening/counseling measures before marriage. Premarital sickle cell screening is an important measure to control, minimize and prevent sickle cell disorders among the youth 
[1]. Sickle Cell Disease (SCD) is an autosomal recessive genetic blood disorder characterized by red blood cells that assume an abnormal, rigid and sickle shape due to mutation in the hemoglobin gene [2]. This sickle shape decreases the red blood cells' flexibility and causes vascular-occlusive complications such as painful episodes at extremities and chest, stroke, priapism, liver disease, leg ulcers, spontaneous abortion and renal insufficiency, among others [2]. A person who receives one defective gene from both father and mother develops the disease, while a person who receives one defective and one healthy gene remains healthy but can pass on the disease so, he/she is known as a carrier [3]. According to the World Health Organization, sickle cell disorder contributes $5 \%$ of under-five deaths on the African continent; more than $9 \%$ of such deaths occur in West Africa and up to $16 \%$ of under-five deaths in individual West African countries $[1,4]$. Study had revealed that about one hundred and fifty thousand children are born each year with sickle cell diseases and about $2-3 \%$ of Nigerians live with the disease, while $25-30 \%$ of Nigerians carried the defective gene that can give rise to sickle cell disease [4]. It is estimated that by the year 2025, a total number of 50,000 children born in Nigeria will be affected with the sickle cell disorder, and this poses a great concern $[1,4,5]$. Nigeria has the highest number of sickle cell disease sufferers (a genetic disease) in the world with prevalence found to be 10 persons with sickle cell disease per 1,000 population or $2 \%[5,6]$. In order to prevent this disorder, sickle cell screening/counseling has been recommended for couples before marriage [6]. If two parents who are carriers have a child, there is a 1-in-4 chance of their child developing the disease and a 1-in-2 chance of being just a carrier [7]. Considering this fact, information about the premarital sickle cell screening and counseling before marriage could serve as an important tool towards preventing sickle cell disorder [7]. It could also help to achieve the desired level of knowledge and a change in attitude. Undertaking premarital sickle cell screening and counseling may depend on individual's knowledge of the sickle cell disorder [7]. Although the knowledge gained about premarital sickle cell screening/counseling could help to prevent SCD but positive attitudinal behavior of the intending couples towards screening/counseling could lead to eradication of the sickle cell genetic disease in Nigeria.

Theory of Reasoned Action (TRA) and Theory of Planned Behavior (TPB) were applied to this study [8]. The theories stated that behavior is a function of attitude and subjective norms [8]. The practices of sickle cell screening test could improve if participants are aware of the benefit of the compliance like reduction in high risk marriages, reducing sickle cell diseases burden to barest minimum, as well as reduction in under-five mortality and morbidity rate. Furthermore, the subjective norms regarding action could influence the participants to show adherence or no adherence [8]. Alternatively, motivation to comply could influence participants to engage in positive behavior. Therefore, it could be suggested that the more favorable the attitude and the subjective norm, the better the intention and willing behavior to comply with sickle cell genetic screening [8]. Applying the theory to this study shows that positive attitudes towards practices of premarital sickle cell screening could prevent genetic disease [8]. Conclusively, the practice of premarital sickle cell screening/counseling to prevent sickle cell disorder remains the realistic approach towards reduction of the ill health impact and mortality related to sickle cell disease among the populace [9].

This study was conducted to fill the gap in literature as many studies had been published on premarital sickle cell genetic screening. But there is a knowledge gap on the comparison of the knowledge, attitude and practice of the married and unmarried youths in Nigeria. Hence, this study was conducted to assess the level of knowledge, attitude and practices of premarital sickle cell screening among the youths. The influences of the independent variables like gender, age, marital status, family history of sickle cell disease were examined. Also, an association that exists between outcome variable (practices of sickle cell screening) and independent variables (knowledge and attitude towards premarital sickle cell genetic screening) among the youth (married and unmarried) of Epe, Nigeria was established. The significance of this study is that the outcome could serve as tools for stakeholders; government and healthcare providers in identifying areas that need attention and proffer solution to those issues that could hinder participants from complying with premarital sickle cell genetic screening/counseling.

\section{Method}

\subsection{Research Design and Participants}

This study was conducted between August 12 and November 17, 2016 in Epe, Nigeria. A cross-sectional descriptive survey design was used. The design could be used to investigate events as they occur in their natural settings [9]. Therefore, it was assumed that the design was appropriate for this study that assessed the knowledge and attitude of the youth in relation to practices of premarital sickle cell screening/counseling. The participants included were youths attending tutorial coaching centers and undergraduates of the Lagos State University, Epe campus. The $N=370$ participants were randomly selected using a nonprobability sampling technique during the survey.

\subsection{Sample Size Determination}

Krejcies and Morgan's [10] formula for determining sample size of a population was used.

$$
S=\frac{\mathrm{X} 2 \mathrm{NP}(1-\mathrm{P})}{\mathrm{d} 2(\mathrm{~N}-1)+\mathrm{X} 2 \mathrm{P}(1-\mathrm{P})}
$$

$\mathrm{S}=$ required sample size.

$X^{2}=$ the table value of chi-square for 1 degree of freedom at the desired confidence level (3.841)

$N=$ the population size.

$\mathrm{P}=$ the population proportion (assumed to be 0.50 since 
this would provide the maximum sample size).

$\mathrm{d}=$ the degree of accuracy expresses as a proportion $(0.05)$.

$X^{2}=$ table value of chi-square at degree of freedom $=1$ for desired confidence level; $10=2.71, .05=3.84, .01=$ $6.64, .001=10.84$.

$$
\begin{gathered}
S=\frac{(3.841)(10,400)(0.5)(1-0.5)}{(0.05) 2(10,400-1)+(3.841)(0.5)(1-0.5)} \\
S=\frac{9986.60}{25.9975+0.9603} \\
S=\frac{9986.60}{26.96} \\
S=370
\end{gathered}
$$

\subsection{Instrument and Measurement of Variables}

The instrument used for data collection was a structured questionnaire. The questions were based on stated objectives and literatures reviewed on premarital sickle cell screening. The questionnaire was made up of four sections. In section $\mathrm{A}$, the participants were required to provide the demographic information such as age group, marital status, gender, etc. Section $\mathrm{B}, \mathrm{C}$ and $\mathrm{D}$ contained questions on knowledge, attitude and practice of premarital sickle cell screening respectively. Knowledge questions were rated with "YES", "NO" and "DO NOT KNOW" but assessed using the mean score of 8.5 for items 6-9 of the questionnaire. Scores above 8.5 was considered good knowledge, while scores below 8.5 was regarded as poor knowledge. A four-point rating scale that ranged from strongly agree $=1$, Agree $=2$, disagree $=3$, to strongly disagree $=4$, was used to measure attitude. Under the attitude scale, items 10-12 of the questionnaire were worded positive while items 13-18 were worded negative. The positive items were rated 4 and 3, while all negatively worded items were reverse scored, that is, score of 4 was rated 1, and 3 was rated 2 etc. Individual mean score was used to find the total mean score of the participants. A positive attitude was indicated by a mean score above 2.5 and this showed participants who agreed and strongly agreed to the correct answers, while mean scores below 2.5 shows participants who disagreed and strongly disagreed to the correct answers. Practice was assessed using the mean score of 8.5 for the items on practices in the questionnaire. Scores above 8.5 was considered good practice, while scores below 8.5 was regarded as poor practices. All the variables in sections $\mathrm{B}, \mathrm{C}, \& \mathrm{D}$ were changed to categorical variable for analysis of the data.

\subsection{Validity/Reliability of the Instrument}

Pilot study was conducted to test the validity and reliability of the instrument used for the survey by administering $10 \%$ of 370 questionnaires, which were 37 questionnaires to youths (married and unmarried) from a nearby town that was far away from the study setting but had similar characteristics with the study subjects. The face, constructs and content validity of the instrument were ascertained and found to be appropriate. Reliability of the instrument was determined through test re-test method. The two sets of 37 questionnaires were administered to the same participants at 2 weeks interval. The test re-test scores from the two sets of data were subjected to statistical test using Cranach's' Alpha correlation co-efficient to determine the internal consistency of the instrument. Reliability co-efficient value of 0.809 was obtained, which indicated a strong positive correlation and synchronization of the questions in the questionnaire.

\subsection{Data Collection Procedure and Analysis}

The participants were invited to participate in the study using proportional stratified sampling technique selection method and requesting them to fill the consent form before participation. The administration of the questionnaire was during the day and participation was voluntary. The questionnaires were administered to those participants who met the inclusion criteria. Data were collected daily for 4 weeks from the participants until $N=370$ were achieved. The questionnaires filled were collected on the spot. The data were collated and tallied before input into the computer for analysis. Descriptive statistics, including frequencies, percentages, mean and standard deviation, were used to present the data. Chi-square was used to test the hypotheses at $p<0.05$ levels of significant, while Cramer's V ranging from 0.00 to 0.99 was used to test the strength of the hypotheses. The statistical analyses were performed using SPSS version 21 statistical package for social sciences.

\subsection{Study Ethical Considerations}

The study was approved by the research committee of the National Open University, Nigeria prior to data collection. A written implied consent was obtained from the participants before administering the questionnaire to them. The participants were ensured of confidentiality of the data collected. All the procedures involving participation of human being in the research study were adhered to throughout the conduct of this study.

\section{Results}

\subsection{Participants Demographic Characteristics}

In this study, 370 questionnaires administered were successfully retrieved giving a return rate of $100 \%$. Table 1 shows that 167 (45.1\%) of the participants were males, while, $203(54.9 \%)$ were females. The mean age of the participants $m=23.48$ years with a $S D=8.77$. Majority of the participants $304(82.2 \%)$ fall within the age group of 13-22 years, while, $4(1 \%)$ were in age group 33-37 years. Similarly, 300 $(81.08 \%)$ of the participants were not married, while 70 (18.91\%) were married. One-fifth $84(22.7 \%)$ of the participants reported family history of sickle cell disease, 246 $(66.5 \%)$ reported no family history of sickle cell diseases and 
$40(10.5 \%)$ could not affirm.

Table 1. Demographic Characteristics of the Youth, Epe, Lagos, Nigeria, November, 2016.

\begin{tabular}{lll}
\hline Variable & Frequency $(\boldsymbol{N}=\mathbf{3 7 0})$ & Percent\% \\
\hline Gender & & \\
Male & 167 & 45.14 \\
Female & 203 & 54.86 \\
Age & & \\
$13-17$ & 152 & 41.08 \\
$18-22$ & 152 & 41.08 \\
$23-27$ & 51 & 13.80 \\
$28-32$ & 11 & 03.00 \\
$33-37$ & 04 & 01.10 \\
Marital Status & & \\
Married & 70 & 18.91 \\
Unmarried & 300 & 81.08 \\
Sickle cell disease history & & \\
Yes & 84 & 22.70 \\
No & 246 & 66.50 \\
Do not know & 40 & 10.00 \\
\hline
\end{tabular}

\subsection{Demographic Variable and Level of Knowledge, Attitude and Practices}

Table 2 shows level of knowledge, attitude and practices of premarital sickle cell genetic screening among the participants. Majority of the unmarried youths $n=203$. $67.66 \%$ had good knowledge of premarital sickle cell screening, while $n=97,32.33 \%$ had poor knowledge of premarital sickle cell screening and $m=13.59, S D=3.87$. The married youths had $m=8.67, S D=2.23, n=60,85.71 \%$ had good knowledge of premarital sickle cell screening, while $n=10,14.28 \%$ had poor knowledge of premarital sickle cell screening/counseling. The mean score for unmarried participants on attitude was $m=2.87>m=2.50$ and $S D=0.622$. The $n=204,70.7 \%$ of the unmarried had positive attitude while $n=86,29.3 \%$ had negative attitude towards sickle cell screening/counseling. The married participants had mean score $m=3.06>m=2.50, S D=0.639$ on attitude with $n=174$, $78.0 \%$ had positive attitude and $n=47,22.0 \%$ had negative attitude towards premarital sickle cell screening/counseling. The mean score for unmarried participants on practice was $m=8.87>m=8.50$ and $S D=0.521$. The $n=102,70.7 \%$ of the unmarried had good practice, while $n=198,29.3 \%$ had poor practice towards sickle cell screening/counseling. The married participants had mean score $m=8.71>m=8.50$, $S D=0.439$ on practice with $n=31,78.0 \%$ had good practices and $n=39,22.0 \%$ had poor level of practice on premarital sickle cell screening.

Table 2. Demographic variables and level of knowledge, attitude and practice of premarital Sickle cell Screening Epe, Nigeria, November, 2016.

\begin{tabular}{|c|c|c|c|c|c|c|c|}
\hline \multirow{4}{*}{ Variable } & \multicolumn{3}{|c|}{ Level of knowledge } & \multicolumn{2}{|c|}{ Attitude Level } & \multicolumn{2}{|c|}{ Preventive Practice Level } \\
\hline & Rating & Poor & Good & Negative & Positive & Poor & Good \\
\hline & Scores & Score $<8.50$ & Score $>8.50$ & Score $<2.5$ & Score $>2.5$ & Score $<8.50$ & Score $>8.50$ \\
\hline & $N=370(\%)$ & $n=107(\%)$ & $n=263(\%)$ & $n=121(\%)$ & $n=249(\%)$ & $n=237(\%)$ & $n=133(\%)$ \\
\hline Gender & & & & & & & \\
\hline Male & $167(45.14)$ & $64(59.81)$ & $103(39.16)$ & $34(28.10)$ & $133(53.41)$ & $125(52.74)$ & $42(31.58)$ \\
\hline Female & 203(54.86) & $43(40.19)$ & $160(60.84)$ & $87(71.90)$ & $116(46.59)$ & $112(47.26)$ & $91(68.42)$ \\
\hline Age & & & & & & & \\
\hline$\leq 22$ & $304(82.16)$ & $93(86.92)$ & $211(80.23)$ & 104 (85.95) & $200(80.32)$ & $202(85.23)$ & $102(76.69)$ \\
\hline$>22$ & $66(17.84)$ & $14(13.08)$ & $52(19.77)$ & $17(14.05)$ & $49(19.68)$ & $35(14.77)$ & $31(23.31)$ \\
\hline Marital Stat. & & & & & & & \\
\hline Married & $70(18.91)$ & $10(9.35)$ & $60(22.81)$ & $29(23.97)$ & $41(16.47)$ & $39(16.46)$ & $31(23.30)$ \\
\hline $\begin{array}{l}\text { Unmarried } \\
\text { SCD history }\end{array}$ & $300(81.08)$ & $97(90.65)$ & $203(77.19)$ & $92(76.03)$ & $208(83.53)$ & $198(83.54)$ & $102(76.70)$ \\
\hline $\begin{array}{l}\text { Yes } \\
\text { Yestory }\end{array}$ & $84(22.70)$ & $15(14.02)$ & $69(26.24)$ & $25(20.66)$ & $59(23.70)$ & $26(10.97)$ & $56(42.10)$ \\
\hline No & $286(76.50)$ & 92 (85.98) & $194(73.76)$ & $96(79.34)$ & 190 (76.30.) & $211(89.03)$ & $77(57.90)$ \\
\hline
\end{tabular}

\subsection{Test of Hypotheses on Knowledge and Practice of Premarital Sickle Cell Screening}

Table 3 shows test of hypotheses on knowledge and practice of premarital sickle cell screening for married and unmarried youths. It was found that there was significant association between knowledge and practice of premarital sickle cell genetic screening among unmarried youths with
$X^{2}=6.359$, Cramer's v=0.09, $p=0.0116(p<0.05)$. Similarly, for married youths the finding shows there was significant relationship between knowledge and practice of sickle cell genetic screening with $X^{2}=12.9325$, Cramer's $\mathrm{v}=0.10$, $p=0.0003(p<0.05)$. For both married and unmarried youths the null hypotheses were rejected, hence significant association exists between knowledge and practice of premarital sickle cell genetic screening.

Table 3. Knowledge and practice of premarital sickle cell screening Compared among youth of Epe, Nigeria, November, 2016.

\begin{tabular}{llll}
\hline Variable & Premarital sickle cell screening $(\boldsymbol{N}=\mathbf{3 7 0})$ & Statistical analysis \\
\hline & Practices $(\%)$ & Did not practice $(\%)$ & \\
\hline Unmarried & & & $X^{2}=6.359$ \\
Poor knowledge & $63(21.00)$ & $44(14.67)$ & $p=0.0116$ \\
Good knowledge & $141(47.00)$ & $52(17.33)$ & $\mathrm{df}=1$ \\
Total & 204 & 96 & $n=300$ \\
Married & & & 0.09 \\
\hline
\end{tabular}




\begin{tabular}{|c|c|c|c|c|}
\hline \multirow{2}{*}{ Variable } & \multicolumn{2}{|c|}{ Premarital sickle cell screening $(N=370)$} & \multirow{2}{*}{ Statistical analysis } & \multirow{2}{*}{ Crammer's value } \\
\hline & Practices (\%) & Did not practice (\%) & & \\
\hline Poor knowledge & $05(4.28)$ & $21(30.00)$ & $\begin{array}{l}X^{2}=12.932 \\
p=0.0003\end{array}$ & \\
\hline Good knowledge & $28(42.86)$ & $16(22.86)$ & $\mathrm{df}=1$ & \\
\hline Total & 33 & 37 & $n=70$ & 0.10 \\
\hline
\end{tabular}

Table 4. Attitude and practice of premarital sickle cell screening compared among youth of Epe, Nigeria, November, 2016.

\begin{tabular}{|c|c|c|c|c|}
\hline \multirow{2}{*}{ Variable } & \multicolumn{2}{|c|}{ Practice sickle cell Screening $(N=370)$} & \multirow[t]{2}{*}{ Statistical analysis } & \multirow[t]{2}{*}{ Crammer's value } \\
\hline & Practice (\%) & Did not practice (\%) & & \\
\hline \multicolumn{5}{|l|}{ Unmarried } \\
\hline Positive attitude & 32 & 26 & $\begin{array}{l}X^{2}=20.307 \\
p=0.0007\end{array}$ & \\
\hline Negative attitude & 60 & 186 & $\mathrm{df}=1$ & \\
\hline $\begin{array}{l}\text { Total } \\
\text { Married }\end{array}$ & 92 & 208 & $n=300$ & 0.17 \\
\hline Positive attitude & 35 & 23 & $\begin{array}{l}X^{2}=0.0168 \\
p=0.8969\end{array}$ & \\
\hline Negative attitude & 07 & 05 & $\mathrm{df}=1$ & \\
\hline Total & 42 & 28 & $n=70$ & 0.08 \\
\hline
\end{tabular}

\subsection{Test of Hypotheses on Attitude and Practice of Premarital Sickle Cell Screening}

Table 4 shows that there was a significant relationship between attitude and practice of premarital sickle cell screening/counseling among unmarried youths with $X^{2}=20.307$, Cramer's v $=0.17, p=0.0007, d f=1 \quad(p<0.05)$. In contrast, the finding for married youth showed that there was no significant relationship between attitude and practice of sickle cell screening with $X^{2}=0.0168$, Cramer's $\mathrm{v}=0.08$, $p=0.8969, d f=1 \quad(p>0.05)$. For unmarried youths, the null hypothesis was rejected. But for married youths, it was accepted.

\section{Discussion}

This study results revealed the level of knowledge, attitude, practices and the relationship that exists between knowledge, attitude and practice of premarital sickle cell screening among married and unmarried youths of Epe, Nigeria. A sample size of 370 participants was selected using proportional stratified random sampling technique. Data collected were analyzed electronically with SPSS version 21, descriptive statistics was used to report the frequencies, mean and standard deviation, while hypotheses were tested with chi-square at $p<0.05$ level of significance.

Majority of the participants both married and unmarried $n=263,70.06 \%$, had good knowledge of premarital sickle cell screening, they reported it could be done before marriage to rule out sickle cell genetic disorder among the intending couple. This finding is not consistent with that of the study conducted among unmarried female students in Nigeria [11]. In the study, it was found that knowledge of premarital sickle cell screening was poor before genetic educational intervention. But after the educational program, students' knowledge about premarital sickle cell screening improved. The educational interventional program markedly improved the participants' knowledge as the study reported $m=9.5+5.36$ in pre-test and $m=18.45 \pm 14.96$ in the post test. The implication of the study finding is that educational program could have successfully improved the students' knowledge of premarital sickle cell screening. In contrast to the above study, another study conducted in Nigeria on the knowledge and attitude of premarital sickle cell screening is consistent with this study's finding, where most of the participants $(79 \%)$ were aware of the premarital sickle cell screening and their main source of information was school [9]. The outcome of the study emphasizes the importance of health education in the schools and it could be regarded as the key towards improving the knowledge of students about premarital sickle cell genetic screening test [9]. But in this current study, the participants' sources of information include private, mission and public hospitals and medical laboratories. More than half of the participants $n=223$, $60.27 \%$ reported that one of the major benefits of premarital sickle cell screening is to prevent sickle cell genetic disease of the offspring. Also, the participants agreed that prevention of sickle cell disease could reduce risk factors like under-five morbidity, mortality, divorce, separation and disharmony among the couples [12]. Giving birth to a sickle cell carrier was ranked first among the consequences of failure to carry out sickle cell genetic screening test before marriage [12]. Other problems associated with sickle cell disease include financial stress, conflicts at homes and high infant morbidity and mortality [12]. The finding of this study is consistent with the finding of a study which revealed that majority of the studied participants $(63.3 \%)$ had good knowledge of premarital sickle cell screening [12].

The result of the assessment of the participants attitude shows that more than half of the participants $n=249,61.00 \%$ agreed that premarital sickle cell screening is necessary once the couples intended to marry. The finding on attitude in this study is consistent with the findings of a study conducted in southsouth, Nigeria, where the attitude of the students towards premarital screening was positive as $85.9 \%$ reported that premarital sickle cell screening could control the disease [13]. 
Similarly, the result of another study revealed that participants agreed that premarital screening could prevent sickle cell genetic disease of the offspring's [14]. In spite of the positive attitude of more than half of the participants of this study, $40 \%$ expressed negative attitude and reported stigma associated with sickle cell screening since their genetic status would be revealed by the test. They also stated that sickle cell genetic screening could increase the chances of losing their partner. This study finding is consistent with that of the study conducted on attitude towards genetic screening as $38 \%$ of the students' had negative attitude towards premarital sickle cell screening [15]. Also, Al kindi et al. observed that utilization of premarital sickle cell screening is poor due to belief of the participants [9]. Therefore, education programs about the benefits of premarital sickle cell screening could be planned to target the vulnerable groups to enable them make informed decisions before marriage [16].

Furthermore, the findings on the relationship between knowledge and practice of premarital sickle cell screening indicated that knowledge was related to practice, since previous knowledge from the school could influence practice of sickle cell genetic screening before marriage. Also, this study revealed that unmarried youths $n=52$ were not willing to carry out sickle cell genetic screening despite having good knowledge. Therefore, there is need to plan and implement educational programs on sickle cell disease for the youths, so that good knowledge could transform into a high level of practice $[17,18]$. This study result shows that there was a significant relationship between the attitude and practice of premarital sickle cell screening among the youths. The implication of this finding is that as the number of people with positive attitude increases, there is a probability it could increase the practice of premarital sickle cell screening. The result of this study also revealed that there was no significant relationship between attitude and practice of premarital sickle cell screening for the married participants. The implication of this finding is that despite the positive attitude, few percentage of married participants reported poor practices of premarital sickle cell screening and they could not see the importance because they were not favorably disposed to it. This finding reflects the importance of health education as a key to improve the knowledge and influence the attitude of the youth towards premarital sickle cell screening and counseling [19, 20]. Health educators could plan information dissemination that may assist the youth to improve their knowledge on the importance of sickle cell screening. Since fear of stigmatization and confidentiality of the test result are factors reported as militating against unmarried youths to show willingness to carry out the test, then educational program and campaigns could focus on how to dispel the rumors of stigmatization and that confidentiality of the test result could be maintained to allay the fear of isolation or rejection by the society [21,22].

Government could institute a strong policy on mandatory premarital sickle cell genetic screening and religious institutions may be encouraged to ensure proper compliance of intending couples before joining their hands in marriage. The limitation of this study is that it was confined to Lagos
State University campus and secondary school leavers' tutorial centre's in Epe town. Therefore, the findings of this study could not be generalized to all the youth of Epe town or the entire Lagos state or Nigeria. The negative attitudes expressed by the studied youths may not reflect the views of the entire Nigerian youths. Based on this study finding, it is suggested that similar studies should be carried out in another sector's aside the education sector, perhaps using a bigger sample size and in another city in Nigeria. Furthermore, parental roles in making sure their children comply with premarital sickle cell genetic screening before marriage could also be investigated to ascertain parent level of awareness and understanding of the importance of premarital sickle cell screening and counseling.

\section{Conclusion}

This study revealed good knowledge, negative attitude and poor practices of premarital sickle cell screening among the married and unmarried participants. Sickle cell disorder is a known genetic disease characterized by inheritance of abnormal gene, which interferes with the normal body functions and leads to frequent hospitalization for treatment and death of the affected person's especially in a resource limited developing countries like Nigeria. Considering the associated health problem it could be emphasized that imbibing the culture of premarital sickle cell screening by intending couples is the most cost-effective intervention that could end the threat of the sickle cell genetic disorder.

\section{Author's Contribution}

TOR: Design, conceptualized, analyzed data and prepared the study manuscript

WAA: Supervised and proof read the study

ROA: Coordinated data entry into computer statistical software and proof read the study

RAA: Collected data and prepared study write up

\section{Conflict of Interest}

Authors declared that they do not have conflict of interest.

\section{References}

[1] WHO. Sickle-cell disease and other hemoglobin disorders. 2016; 1-3. Retrieved from

http://www.who.int/mediacentre/factsheets/fs308/en/

[2] Genetic Learning Center. Genetic disorders. 2016; 1-7. Retrieved from http://www.learngenetics_utah.edu/content/disorders

[3] Saraf SL, Molokie RE, Nouraie M, Sable CA, LuchtmanJones L. Differences in the clinical and genotypic presentation of sickle cell disease around the world. Pediatrics Respiratory Reviews. 2014; 15(1): 4-12. 
[4] Nnaji GA, Ezeagwuna DA, NnajiI JF, Osakwe JO, Nwigwe AC. Prevalence and pattern of sickle cell disease in premarital couples in Southeastern Nigeria. Nigerian $J$ of Clinical Practice. 2013; 16(3): 309-314.

[5] Chakravorty S, Williams TN. Sickle cell disease: a neglected chronic disease of increasing global health importance. Archives of Disease in Childhood. 2015; 100(1): 48-53.

[6] Oyedele EA, Emmanuel A, Gaji LD, Ahure DOE. Awareness and acceptance of premarital genotype screening among youths in a Nigerian community. Internatl $\mathrm{J}$ of Medical and Health Research. 2015; 1(1): 17-21. Retrieved from http://discover.saemobilus.org/scholarlyjournalsbing?utm_sou rce=bing\%26utm_campaign=NTN-Scholarly_JournalsMB\%26utm_device $=\mathrm{c} \% 26 \mathrm{utm} \_$medium $=\mathrm{cpc} \% 26 \mathrm{utm} \_$content $=81157718894812 \% 26$ utm term $=\% 2$ Binternational $\% 20 \% 2 \mathrm{Bj}$ ournal\%26utm_keymatch $=$ p\%26utm_adpostion $=\{$ adpostion $\}$ $\% 26$ utm phone $=833-539-4592$

[7] Anie KA, Akinyanju OO, Egunjobi FE. Psychosocial impact of sickle cell disorder: perspectives from a Nigerian setting. 2010: University press.

[8] Ajazen I, Fishbein M. Understanding attitudes and predicting. Social Behavior. Eagle wood cliffs. 1980; New Jersey.

[9] Alkindi M. Salha AR, AL-kend M. Knowledge and attitude of University Students towards Premarital Sickle Cell screening Program. Coman medical journal. 2012; 27(4): 291 - 296.

[10] Krejcie RV, Morgan DW. Determining sample size for research activities. Educational and psychological measurement. 1970; 30: 607-610.

[11] Omuemu VO, Obarisiagbon OE, Ogboghodo EO. Awareness and acceptability of premarital screening of sickle cell disease among undergraduate students of the University of Benin, Benin City, Edo State. J of Med. and Biomedical Research. 2013; 12(1): 91-104.

[12] Durotoye IA, Salaudeen AG, Babatunde AS, Bosah EC. Knowledge and perception of sickle cell disease among senior secondary school students in Ilorin metropolis. The Tropical J of Health Sciences. 2013; 20(2): 1-7. Retrieved fromhttps://www.ajol.info/index.php/tjhc

[13] Gbenol PK, Brisibe SF, Ordinioha B. Knowledge, attitude and uptake of premarital screening for the sickle trait among married couples in a semi urban community in South-South Nigeria. European J of Prev. Med. 2015; 3: 49-54. https://doiorg.ezp.waldenulibrary.org/10.11648/j.ejpm.20150303.13

[14] Adewoyin AS. Management of sickle cell disease: a review for physician education in Nigeria (sub-saharan Africa). National Library of Medicine. Anemia. 2015; 791498.

[15] Aneke J, Okocha C. Sickle cell disease genetic counseling and testing: A review Alternate title: Review Article. Archives of Med. and Health Sciences. 2016; 4(1): 50.

[16] Nnodu OE. Interventions for the prevention of sickle cell disease at primary health care centres in Gwagwalada area council of the Federal Capital Territory, Nigeria. Cureus. 2014; 6(8): e194. doi:10. 7759/cureus. 194

[17] Ogun GO, Ebili H, Kotila TR. Autopsy findings and pattern of mortality in Nigerian sickle cell disease patients. National Library of Medicine. The Pan African Medical J. 2014; 18: 30 .

[18] Grosse SD, Odame I, Atrash HK, Amendah DD, Piel FB. Sickle cell disease in Africa: A neglected cause of early childhood mortality. American J of Prev. Med. 2011; 41(6): Suppl 4, S398-S405.

[19] Afolayan JA, Jolayemi FT. Parental Attitude to Children with Sickle Cell Disease in Selected Health Facilities in Irepodun Local Government, Kwara State, Nigeria Studies on EthnoMedicine. 2011; (1): 33-40.

[20] Fernandes AP, Pinheiro C, Januário JN, Cangussu CB, Macedo DL, Viana MB. Mortality of children with sickle cell disease: a population study. Jornal de Pediatria. 2010. 86(4): 279-284.

[21] Abioye-Kuteyi EA, Oyegbade O, Bello I, Osakwe C. Sickle cell knowledge, premarital screening and marital decisions among local government workers in Ile-Ife, Nigeria. African J of Primary Health Care and Family Med. 2009; 1(1): Article 22. African Online Scientific Information Systems/AOSIS (Pty) Ltd

[22] Moronkola OA, Fadairo RA. University students in Nigeria: knowledge, attitude toward sickle cell disease, and genetic counseling before marriage. National Library of Medicine. Internatl Quarterly J of Comm. Health Edu. 2007; 26(1): 8593. 